Seevers. A coal mining town about three miles southeast of Co!fax. Post office, 1903-14.

Sugar Creek. In the southeastern part of Richland 'Township. Post office, 1862-71.

Tool's Ponv't. The name first given to the present town of Monroe. It was platted in 1850 as Tool's Point, and the post office received the same name, but the change was made to Monroe a year or two later.

Turver. A former station on the C., R. I. \& P. Railway in Rock Creek Township.

VANDALA, A village in the southwest portion of section 20, Des Moines Township. It was laid out in 1853 and was prosperous in the 1860's. Post office, 1857-1903.

Vownt.s. The name by which Farmersville (which see above) was first shown on the maps.

Warres Grove. I.isted in the U.S. Official Register as a post office in Jasper County from 1869 to 1871 , but not found on the maps of that period.

Wilf.inysvin.e. Listed in the 1869 U. S. Official Register as a post oftice in Jasper County, and thought to have been in the neighborhood of Woodville, which see below.

Woopvins. A station on the Des Moines Valley Railroad in the western part of Washington 'Township, as shown on maps from 1868 to 1878 .

WiTtemburg. In the eastern part of section 3, Newton Township, about four miles north of the city of Newton. It was platted in 1856, and the Wittemburg Manual Labor College was established there. A Congregational church still remains.

(To be continued)

\title{
STEAMBOAT LEAVES DES MOINES
}

The Des Moines City [steamboat] went down yesterday loaded with a considerable drove of hogs. The grunters manifested a characteristic disposition to be stubborn, but after being surrounded and pushed up by several squads, battalions and regiments of folks, they were finally induced to go aboard, and take a voyage for their health.-Daily State.Register, Des Moines, Iowa, May 2, 1862. (In the Historical, Memorial and Art Department of Iowa.) 
Copyright of Annals of Iowa is the property of State of Iowa, by \& through the State Historical Society of Iowa and its content may not be copied or emailed to multiple sites or posted to a listserv without the copyright holder's express written permission. However, users may print, download, or email articles for individual use. 